\title{
Immunohistochemical expression of B and T-lymphocytes and TGF- $\beta$ in experimentally transplanted canine venereal tumor
}

\author{
Expressão imunoistoquímica de linfócitos T e B e do TGF- $\beta$ no tumor venéreo transmissível canino \\ experimentalmente transplantado
}

\author{
Ana Carolina Trompieri -Silveira ${ }^{\mathrm{I}^{*}}$ Daniel Gerardi $^{\mathrm{II}}$ Juliana Vitti Mouro ${ }^{\mathrm{II}}$ Mirela Tinucci Costa ${ }^{\mathrm{II}}$ \\ Antonio Carlos Alessi ${ }^{\mathrm{I}}$
}

\begin{abstract}
The tumor/host relationship may have a determining role in the progression or remission of a tumor. Greater infiltration of leukocytes into tumors has been associated with a better prognosis, although controversy regarding whether these cells have a central role in antitumor immunity still exists. Canine transmissible venereal tumor (TVT) is an experimentally transplantable type of tumor that has been used as an experimental model for the tumor/host relationship. The aim of this study was to evaluate the infiltration of T-lymphocytes (CD3, CD4, CD8) and B lymphocytes (CD79- $\alpha$ ) and the expression of the cytokine TGF- $\beta$ in TVT, by means of immunohistochemistry ( $A B C$ method). The experimental tumors were composed of puppies that developed TVT after transplantation, in the progression $(n=8)$ (Group 1a), latency $(n=8)$ (Group $1 b)$ and regression $(n=8)$ (Group 1c) phases of the tumor. $\mathrm{CD}^{+}$T-lymphocytes predominated in the progression and regression phases, in relation to the latency phase. $\mathrm{CD}^{+}$ and ${ }^{1} \mathrm{CD} 8^{+}$T-lymphocytes were predominant in the progression phase, and with lower expression in the regression phase. The greatest quantities of B-lymphocytes were in the regression phase, with restricted expression in the progression phase. TGF$\beta$ was expressed equally in the phases of the transplanted TVT.
\end{abstract}

Key words: lymphocytes, TVT, immunohistochemistry, dog.

\section{RESUMO}

A relação tumor/hospedeiro pode ter um papel determinante na progressão ou remissão de um tumor. Uma maior infiltração de leucócitos nos tumores tem sido associada a um melhor prognóstico. Entretanto, o papel central dessas células na imunidade antitumoral ainda é controverso. O tumor venéreo transmissível (TVT) canino é um tumor transplantável experimentalmente e tem sido utilizado como modelo experimental da relação tumor versus hospedeiro. O objetivo

\begin{abstract}
deste estudo foi avaliar a infiltração de linfócitos T (CD3, CD4, CD8), B (CD79- $\alpha$ ) e a expressão da citocina TGF- $\beta$ no TVT por meio da imunoistoquímica (método $A B C$ ). Os grupos experimentais foram constituídos por filhotes de cães que desenvolveram o TVT após transplantação nas fases de progressão $(n=8)$ (Grupo 1a), latência $(n=8)$ (Grupo 1b) e regressão $(n=8)$ (Grupo $1 c)$ do tumor. Os linfócitos $T \mathrm{CD}^{+}$ predominaram nas fases de progressão e regressão em relação à fase de latência. Os linfócitos $T \mathrm{CD}^{+}$e $\mathrm{CD} 8^{+}$apresentaram predomínio na fase de progressão e menor expressividade na fase de regressão. Os linfócitos $B$ estavam em maior quantidade na fase de regressão e foram pouco expressivos na fase de progressão. O TGF- $\beta$ foi igualmente expressivo nas fases do TVT transplantado.
\end{abstract}

Palavras-chave: linfócitos, TVT, imunoistoquímica, cão.

\section{INTRODUCTION}

Transmissible venereal tumor (TVT) is a type of neoplasia that occurs naturally among dogs and is transmitted during copulation (ETTINGER \& FELDMAN, 2000). It can also be transmitted experimentally (YANG \& JONES, 1973; YANG et al., 1991; TINUCCI-COSTA, 1999). Studies have demonstrated that greater expression of CD3 Tlymphocytes (MIZUNO et al., 1989; PÉREZ et al., 1998), CD4 and CD8 T-lymphocytes (GONZALEZ et al., 2000), B-lymphocytes, macrophages and the major histocompatibility complex (YANG et al., 1987; PÉREZ et al., 1998) are associated with the regression phase of TVT.

'Departamento de Patologia Veterinária, Universidade Estadual Paulista (UNESP), Via de acesso Professor Paulo Donato Castellani, s/n, 14884-900, Jaboticabal, SP, Brasil. E-mail: actrompieri@yahoo.com.br. *Autor para correspondência.

IIDepartamento de Clínica e Cirurgia Veterinária, UNESP, Jaboticabal, SP, Brasil. 
Although the lymphocytic infiltrate is considered to be a manifestation of the immune response against cancer, controversy regarding whether T cells have a central role in antitumor immunity still exists (O'SULLIVAN; LEWIS, 1994; GAJEWSKI, 2006). It has been shown in the literature that certain mechanisms may block the effect of the immune response on tumors, including weak activation of Tlymphocytes due to low expression of MHC I molecules, extrinsic suppression by regulatory $\mathrm{T}$ cells, insufficient presentation of antigenic peptides, blocking of costimulation and production of suppressive factors by tumor cells in the tumor environment (ZOU, 2006).

Since spontaneous regression of TVT is associated with intense local infiltration of lymphocytes, this neoplasm has been used as a model for studying the mechanisms of the immune response that are involved in tumor regression (MIZUNO et al., 1989). Tumor/host interaction may have an important role in determining the immune response against the tumor. Experiments on human tumors have suggested that the interactions between tumor and host cells might have stimulatory and inhibitory effects on antitumor immunity, resulting from the heterogenous cell composition of the infiltrated cells and the different interactions between these and the tumor cells, with varying prognostic significance(O'SULLIVAN; LEWIS, 1994; YANASE et al., 1995; LUSTER, 2002.).

The aims of the present study were to identify and quantify the T-lymphocytes (CD3 ${ }^{+}, \mathrm{CD} 4^{+}$ and $\mathrm{CD}^{+}$), B-lymphocytes (CD79 $\alpha$ ) and transforming growth factor beta (TGF- $\beta$ ) in canine transmissible venereal tumor from allogenic transplants in the progression, latency and regression phases, by means of immunohistochemistry.

\section{MATERIAL AND METHODS}

Specimens

To use the animals in this experiment, the authors were granted approval by CEBEA (ethics and animal welfare committee)

The transplanted TVT cells were obtained in the following way. Eight 6-month-old mixed-breed dogs of not known history of exposure to TVT (five females and three males), were inoculated subcutaneously at the interscapular region with $1 \mathrm{cc}$ of the tumor cell suspensions containing $1 \times 10^{8}$ viable cells. The dogs were inspected every other day to determine the day of appearance of a palpable lesion, as proposed by YANG \& JONES (1973).
The development of the tumor was followed by measuring its area, which became prominent under the skin. The external margins of the tumor was marked out on transparent thin plastic film, using a ballpoint pen, and the outline was transferred to tracing paper. The tumor area was calculated at the Department of Rural Engineering, FCAV, UNESP, Jaboticabal, with the aid of a compensating polar planimeter (OTT, Kempten, Germany).

Tumors that, from three consecutive measurements, that demonstrated increasing, stationary or decreasing dimensions were considered to be tumors in the progression, latency and regression phases, respectively (TINUCCI-COSTA et al., personal communication). After determining the tumor phase, extraction was then performed. Three tumor specimens were removed from each dog: one in each phase of development.

Twenty-four specimens of TVT, obtained from eight puppies that developed TVT after allogenic transplantation were fixed in $10 \%$ formalin solution and routinely processed for histopathological. These were distributed as follows group a: TVT in the progression phase $(n=8)$, group b: TVT in the latency phase $(n=8)$ and group c: TVT in the regression phase $(\mathrm{n}=8)$.

\section{Immunohistochemistry}

The immunohistochemistry procedure used was the avidin-biotin-peroxidase complex (ABC) method, done manually. The tissues were labeled with anti-CD3 (clone F7.2.38, DAKO A/S, Denmark), antiCD4(clone DH29A0, VMRD, WA, USA), anti-CD8 (clone CADO46, VMRD, WA, USA), anti-CD79- $\alpha$ (clone HM57, DAKO A/S, Denmark) and anti-TGF-B (clone SC-146, Santa Cruz Biotechnology) at the following dilutions: $1 / 100,1 / 20,1 / 20,1 / 20$ and $1 / 100$, respectively. After incubation with the monoclonal primary antibodies, the slides were incubated with secondary biotinylated antibody (Kit DAKO L SAB + SystemHRP). Next, all the slides were incubated with streptavidin conjugated with peroxidase(Kit DAKO L SAB + System-HRP). The reaction was developed by using a chromogenic substrate (DAKO liquid DAB). The tissues were then counterstained using Harris hematoxylin (1-2 minutes).

To quantify the frequency of immunolabeling, five fields per slide were randomly selected, independent of whether the field was poorly or densely populated. A total of 100 cells were counted in each field, including both labeled and unlabeled cells, using the 20x objective. The numbers of positive and negative cells were counted in order to calculate the 
percentage of labeled cells relative to the total number of cells.

The reactions were carried out in the immunochemistry laboratory, Department of Animal Pathology, FCAV, UNESP, Jaboticabal.

\section{Statistical Analysis}

To compare the mean counts of infiltrated cells in the transplanted TVT (progression, latency and regression), variance analysis (ANOVA) was used with the $\mathrm{F}$ (factor) test. Multiple comparisons of the means were performed using the t test. The software System for Elementary Statistical Analysis (SAS), version 8.0, was used for the analyses.

\section{RESULTS}

Tumors from dogs contained uniform populations of large cells, round or oval in shape with scant but well-defined cytoplasm, arranged in compact groups. The nuclear chromatin was fine and diffusely distributed, and the nuclei, which were ovoid and large, contained prominent, centrally placed nucleoli.

Anti-CD3 antibodies, which were used as a marker for normal or neoplastic T lymphocytes, reacted with lymphocytes located inside or around the tumors. There was a significant difference $(\mathrm{P}<0.05)$ between the experimental phase a and $\mathrm{b}$ (Figure 1A, 1B), b and c (Table 1).

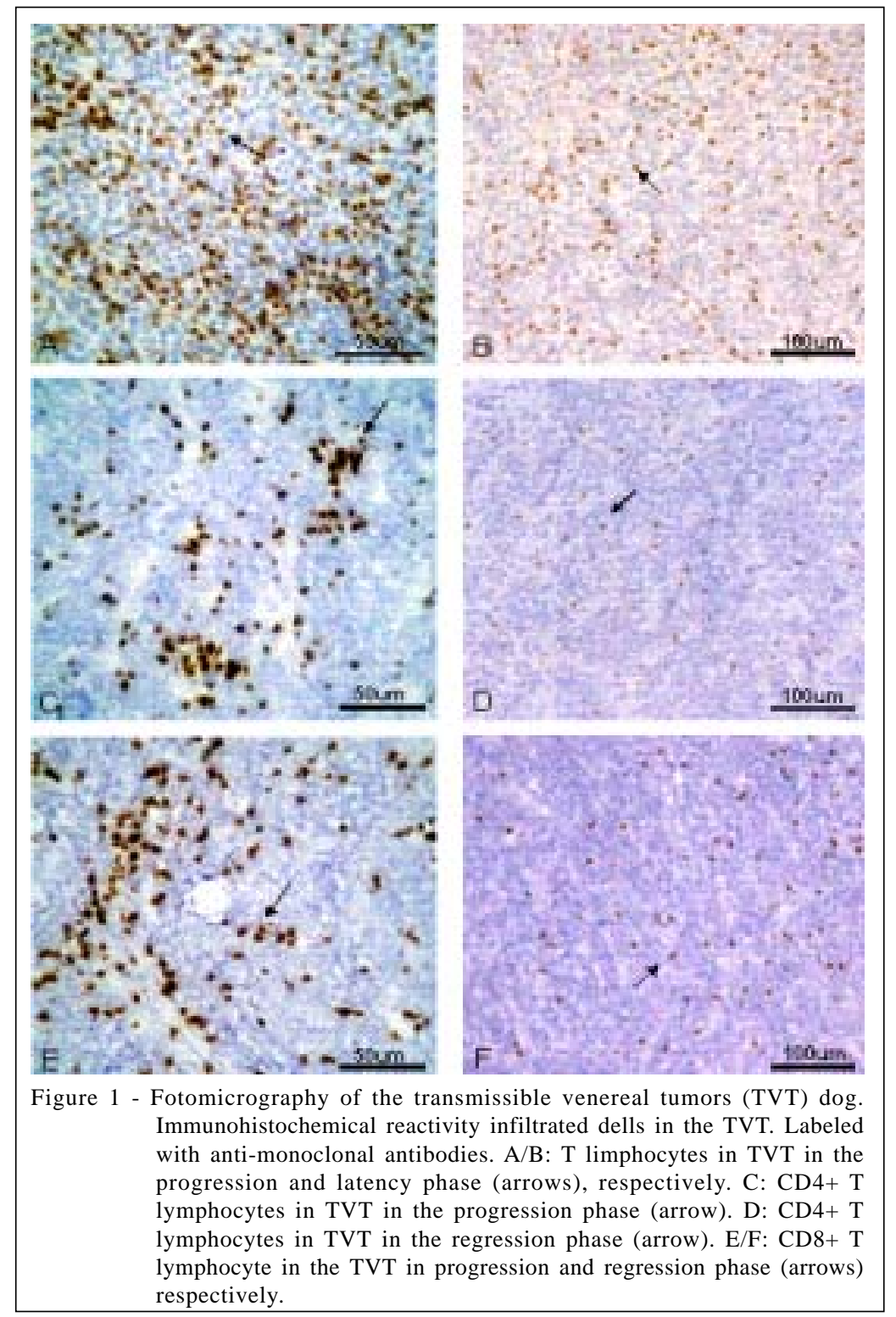

Ciência Rural, v.39, n.4, jul, 2009. 
Table 1 - Average counts of positively-labeled cells in TVT.

\begin{tabular}{|c|c|c|c|c|c|}
\hline & \multicolumn{5}{|c|}{ Immunological markers } \\
\hline Experimental phase & $\mathrm{CD}^{+}$ & $\mathrm{CD}^{+}$ & $\mathrm{CD}^{+}$ & $\mathrm{CD} 79 \alpha^{+}$ & TGF- $\beta^{+}$ \\
\hline Progression & $5.3675^{\mathrm{a}}$ & $5.1922^{\mathrm{a}}$ & $4.9527^{\mathrm{a}}$ & $1.6839^{c}$ & $3.7219^{\mathrm{a}}$ \\
\hline Latency & $4.6537^{\mathrm{b}}$ & $4.4111^{\mathrm{b}}$ & $4.3916^{\mathrm{b}}$ & $2.0105^{\mathrm{b}}$ & $3.7059^{\mathrm{a}}$ \\
\hline Regression & $5.1400^{\mathrm{a}}$ & $2.2719^{c}$ & $2.5413^{\mathrm{c}}$ & $3.0249^{\mathrm{a}}$ & $3.6218^{\mathrm{a}}$ \\
\hline
\end{tabular}

*means with different letters differed within the same row $(\mathrm{P}<0.05)$.

The cells marked with anti-CD4 antibodies were located close to the septae of the conjunctive that was interspersed throughout the tumor tissue. Few of these cells were located at the periphery of the tumor. There were significant differences $(\mathrm{P}<0.05)$ between all the experimental phases (Table 1 ).

The T CD8+ cells were distributed with and demonstrated staining pattern that was very similar to what was observed by the anti-CD4 antibodies, as shown in figure 1C. The use of monoclonal anti-CD8 antibodies for immunophenotyping cytotoxic $\mathrm{T}$ lymphocytes reveal significant differences $(\mathrm{P}<0.05)$ between all the experimental phases (Table 1).

The cells immunolabeled by the cytokine TGF- $\beta$ were distributed both at the periphery of the sections and in small randomly located groups. These were rarely observed isolated. There were no significant differences $(\mathrm{P}<0.05)$ between the experimental phases (Table 1).

Cells immunolabeled by anti-CD79- $\alpha$ antibodies were seen in all the experimental groups. These cells were scattered throughout the section and made up only a small proportion of the cell population. There were significant differences $(\mathrm{P}<0.05)$ between all the experimental phases (Table 1).

\section{DISCUSSION}

The percentages of $\mathrm{T}$ cells were greater during the progression phase of the tumor, except for $\mathrm{CD}^{+}$T-lymphocytes, which were present in the same proportions within the progression and regression phases of the transplanted tumor. These findings are not in agreement with the observations made by MIZUNO et al. (1989), who observed significantly greater proportions of $\mathrm{CD}^{+} \mathrm{T}$-lymphocytes within the inflammatory infiltrate of the tumor, regional lymph nodes and peripheral blood of dogs with tumors in the regression phase, when compared to those in the progression phase. These authors also observed that the lower quantity of T-lymphocyte infiltrate during tumor progression coincided with decreased quantity of lymphocytes of the peripheral blood. This led them to suggest that factors present in the serum of dogs with TVT might inhibit the proliferation of lymphocytes and consequently facilitate tumor growth during the progression phase. PÉREZ et al. (1998) also found that $\mathrm{CD}^{+} \mathrm{T}$-lymphocytes were expressed in large quantities during the regression phase, thus coinciding with the report by MIZUNO et al. (1989), which led them to suggest that these cells might participate in tumor regression. This could not be confirmed from the present study, considering that $\mathrm{CD}^{+} \mathrm{T}$-lymphocytes were found at similar concentrations in the progression and regression phases of the transplanted TVT.

Relative to the T-lymphocyte subtypes CD4 ${ }^{+}$ and $\mathrm{T} \mathrm{CD8}{ }^{+}$, it is of interest to note that their quantities were similarly increased during the tumor progression phase in comparison with the regression phase (Figures 1C, 1D, 1E,1F). This contrasts with the literature, in which these lymphocyte subtypes have been described as large proportions within the tumor regression phase. GONZALEZ et al. (2000) demonstrated the number of $\mathrm{CD}^{+}$T-lymphocytes and CD8 ${ }^{+}$T-lymphocytes were significantly greater during the tumor regression phase than during the progression phase. These authors confirmed their findings by means of the hemocytometry method, where the total percentage of lymphocytes was $52.4 \%$ in the regression phase and $39.6 \%$ in the progression phase. In both phases, the number of $\mathrm{CD}^{+} \mathrm{T}$-lymphocytes was greater than the number of CD4+ T-lymphocytes.

However, the same research group as in the present experiment, in an earlier study, working with the same histopathological specimens as those now used, was also unable to correlate greater infiltration of mononuclear cells with regression of the transplanted TVT. This may have been related to the time taken for the tumor to develop, a mean of 54.5 to 104 days (unpublished data). This was a relatively short period, considering that the mean length of time cited in the literature (KOIKE et al., 1979) of two to six months for tumor development. It might be suggested that, in the earlier experiment, the phase taken considered to be progression might have been the peak of the regression phase, which would probably explain the results encountered. 
The B+ cells in the present study presented significantly greater expression in the regression phase than in the progression phase (Figure 2A, 2B). This result was similar to what was presented by PÉREZ et al. (1998), who demonstrated significantly increased numbers of $\mathrm{B}$ cells in tumors during the regression phase, in comparison with the progression phase. The high number of $B$ cells found in the infiltrate of transplanted tumors in the regression phase and the low number of these cells in the progression phase of TVT suggested that the local tumor immune response may have an important role in the spontaneous regression of this neoplasia (PÉREZ et al., 1998).

The findings from the present study and those of PÉREZ et al. (1998) are different from those reported by CHANDLER \& YANG (1981). These authors characterized the lymphocytic infiltrate of TVT during the regression phase and observed that, during this phase, $60 \%$ was T-lymphocytes, 26\% Blymphocytes and $14 \%$ null cells. On the other hand, during the progression phase, $34 \%$ were $\mathrm{T}$ lymphocytes, 37\% B-lymphocytes and 26\% null cells.
LIAO et al. (2003) indicated that the tumor cells secreted one or more toxic substances that induced apoptosis of the B-lymphocytes, and that the proportions of $\mathrm{CD}^{+}$and $\mathrm{CD}^{+}$T-lymphocytes were also altered by these toxins. Comparing the results from the study by LIAO et al. (2003) with those from the present study, it can be suggested that the substance mentioned may also have caused apoptosis of Blymphocytes in the study mentioned. This is because in the progression phase, in which tumor cells are more numerous, the quantity of B-lymphocytes was lower while in the regression phase, where tumor cells are less numerous, the quantity of B-lymphocytes was significantly increased.

Cytokines present in the tumor environment may affect tumor growth and survival (HALAK et al., 1999). TGF- $\beta$ is one of the cytokines in the tumor microenvironment that is produced by TVT cells (HSIAO et al., 2004). It is a potent inhibitor of the immune response that allows the tumor to escape from immunological surveillance. What could be seen from the present experiment was that, with tumor shrinkage,

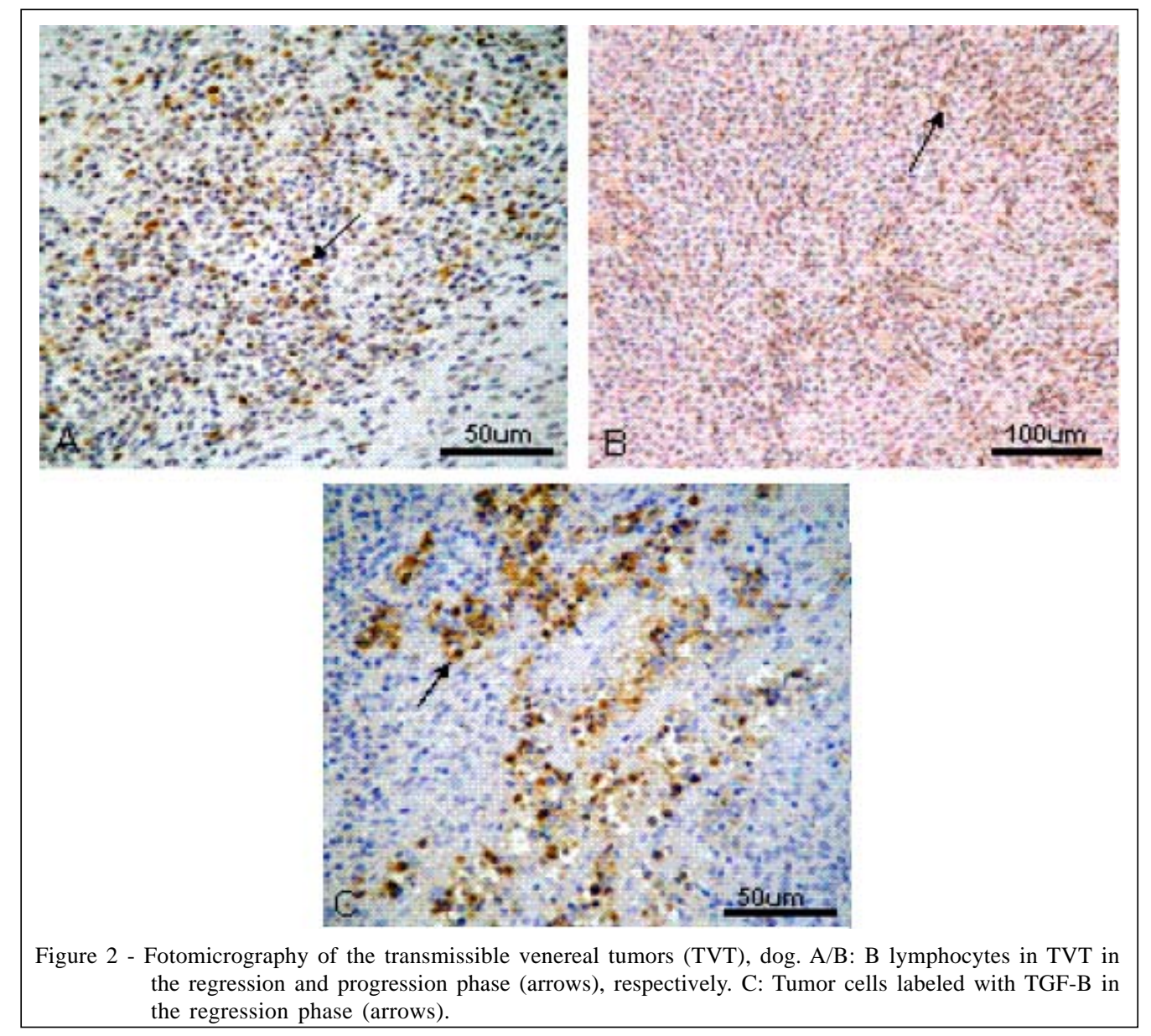

Ciência Rural, v.39, n.4, jul, 2009. 
the concentration of this cytokine in the TVT also regressed (Figure 2C), but without presenting any significant difference between the phases. This confirms what was seen by HSIAO et al. (2004), who used the flow cytometry method and detected high concentrations of TGF- $\beta$ in the supernatant from culturing TVT cells, both in the progression and in the regression phases of the tumor, without any significant difference between them. This led these authors to suggest that the TGF- $\beta$ secreted by the tumor cells would inhibit the proliferation of $\mathrm{T}$ and $\mathrm{B}$ cells and the cytolytic activity of NK cells, thereby allowing the tumor to escape from the immune response. However, despite the powerful inhibition of TGF- $\beta$ on the host's immune cells, tumor regression occurred.

In view of the reports by HSIAO et al. (2004), it can be suggested that the T-lymphocytes that were seen in large quantities during the progression phase of the present experiment were inert. The intense proliferation of T-lymphocytes did not impede tumor growth. This emphasizes that factors within the tumor environment may have been responsible for the impotence of these lymphocytes. Likewise, factors within the same environment may also have been responsible for the reversal of this possible impotence. This likely reversal will have caused the T-lymphocytes to resume their immune response functions, thereby leading to tumor regression.

\section{CONCLUSION}

It was not possible to correlate the development phase of the transplanted TVT with a single predominant type of infiltrate. It can be suggested that, when tumor tissues from different donors are used, there are influences relating to the length of time between transplantation, growth and regression of the TVT and to the quantity of inflammatory cells infiltrated during the progression, latency and regression phases.

\section{ACKNOWLEDGEMENTS}

This work was supported by a grant from the Fundação de Amparo à Pesquisa do Estado de São Paulo (FAPESP) and Conselho Nacional de Desenvolvimento Científico e Tecnológico (CNPq).

\section{REFERENCES}

CHANDLER, J.P., YANG,T.J. Canine transmissible veneral sarcoma: distribution of $\mathrm{T}$ and $\mathrm{B}$ lymphocytes in blood draining lymph nodes and tumors at different stages of growth. British Journal of Cancer, Endiburg, v.44, p.514-521, 1981
GAJEWSKI, T.F. Immune resistance orchestraded by the tumor microenvirinment. Immunological Reviews, Copenhagen, v.213, p.131-145, 2006.

GONZALEZ, C.M. et al. Canine transmisible veneral tumour: a morphological and immunoistochemical study of 11 tumours in growth phase and during regression after chemotherapy. Journal of Comparative Pathology, Endiburg, v.122, p.241248, 2000

HALAK, B. K. et al. Tumor-induced interleukin-10 inhibits type 1 immune responses directed at a tumor antigen as well as a non-tumor antigen present at the tumor site. Cancer Research, Baltimore, v.59, p.911, 1999.

HSIAO, Y.W. et al. Tumor-infiltrating lymphocyte secretion of IL-6 antagonizes tumor-derived TGF-beta 1 and restores the lymphokine-activated killing activity. Journal Immunology, Baltimore, v.3, p.1508-1514, 2004.

ETTINGER, S.J., FELDMAN, E.C. Textbook of veterinary internal medicine: diseases of the dog and cat. Philadelphia: Saunders, 2000. Cap. 102. p.541-546.

KOIKE, T. et al. Clinical examination of canine transmissible venereal sarcoma: relationship between hematological and histological findings. Journal of the Japan Veterinary Medical Association, v.32, n.3, p.137-140, 1979.

LIAO, K.W. et al. Canine transmissible veneral tumor cell depletion of B lymphocytes: molecule(s) specifically toxic for $B$ cell. Veterinary Immunology and Immunopathology, Amsterdam, v.92, p.149-162, 2003.

LUSTER, A.D. The role of chemokines in linking innate and adaptive immunity. Current Opinion in Immunology, London, v.14, p.129-135, 2002. Disponível em: http://www.sciencedirect.com/ science?_ob=ArticleURL\&_udi=B6VS1-44VVK80 N\&_user=687358\&_rdoc $=1 \&$ \&mt $=$ \&_orig=search\&_sort $=$ d\&vie $\mathrm{w}=\mathrm{c} \&$ __a c ct $=$ C $000037899 \&$ \& version $=1 \&$ \&_url V e r s i o n $=0$ \&_u s e r i d = 687358 \& m d 5 $=$ ca1cefef822861e5582816a0c907ec3f. Doi: 10.1016/S09527915(01)00308-9.

MIZUNO, S. et al. Role of lymphocytes in dogs experimentally re-challenged with canine transmissible sarcoma. Japanese Journal of Veterinary Science, Tokio, v.51, n.1, p.86-95, 1989.

O’SULLIVAN, C.; LEWIS, C.E. Tumor-associated leucocytes: Friends or foes in breast cancer carcinoma. Journal of Pathology, Sussex, v.172, p.229-235, 1994.

PÉREZ, J. et al. Immunohistochemical study of the local inflamatory infiltrate in spontaneous canine transmissible venereal tumor at different stages of growth. Veterinary Immunology and Immunopathology, Amsterdam, v.64, p.133-147, 1998.

TINUCCI-COSTA, M. Tumor venéreo transmissível canino: estudos imuno-histoquímicos e de transplantados xenogênicas e alogênicas. 1999. $149 \mathrm{f}$. 
Tese (Doutorado em Patologia Veterinária) - Faculdade de Medicina, Universidade de São Paulo, Ribeirão Preto.

YANASE, M. et al. Cytokines modulate in vitro invasiveness of renal cell carcinoma cells through action on the process of cell attachment to endothelial cells. Journal of Urology, Baltimore, v.153, p.844-848, 1995. Disponível em: http://www.sciencedirect.com/ science?_ob=ArticleURL\&_udi=B7XMT-4HMXJMR$31 \& \_u s e r=687358 \& \_r d o c=1 \& \_f m t=\& \_o r i g=$ search\&_sort $=$ d\&view $=$ c \&_a cct $=$ C000037899\&_version $=1 \&$ \&_urlVersion $=$ 0\&_userid=687358\&md5=7ebb8567c5464c4e43a8b238b41a46de. Doi: 10.1016/S0022-5347(01)67733-4.

YANG, T.J.; JONES, J.B. Canine transmissible venereal sarcoma: transplantation studies in neonatal and adult dogs. Journal of the National Cancer Institute, Bethesda, v.51, p.1915-1918, 1973.

YANG, T.J. et al. Growth stage dependent expression of MHC antigens on the canine transmissible venereal sarcoma. British Journal of Cancer, Endiburg, v.55, p.131-134, 1987.

YANG, T.J. et al. Tumor size, leucocyte adherence inhibition and serum levels of tumor antigen in dogs with the canine transmissible venereal sarcoma. Cancer Immunology and Immunotherapy, Heildeberg, v.33, n.4, p.255-262, 1991.

ZOU, W. Regulatory $\mathrm{T}$ cells, tumor immunity and immunotherapy. Nature Reviews Immunology, London, v.6, p.295-397, 2006. 